\title{
PERIODS OF WEED INTERFERENCE ON TRANSGENIC COTTON 'IMACD 6001LL',
}

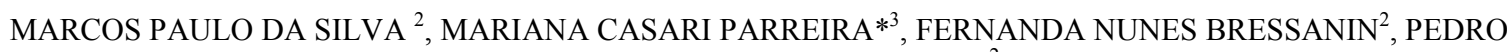 \\ LUIS DA COSTA AGUIAR ALVES ${ }^{2}$
}

\begin{abstract}
The objective of this study was to determine the periods of weed interference and its impact on productivity of cotton 'IMACD 6001LL'. The experiment was conducted in Jaboticabal, São Paulo, the second crop in 2011 and consisted of two treatment groups: the first culture remained free of competing weeds since of emergence up different periods of its development: $(0-15,0-25,0-35,0-45,0-55,0-65,0-75$ and $0-183$ days harvest). In the second treatment group was held to the contrary: the crop was in harmony with the weeds since of emergence up to the same stages of development described above. The treatments were arranged in a randomized block design in four replications. During these periods was evaluated dry matter accumulation by weeds. The cotton yield data were subjected to regression analysis and resulting in a CPWC of 35 DAE, the CPWR was 133 DAE and.The weed community was composed mainly of Raphanus raphanistrum, Amaranthus spp., Cyperus rotundus, Alternanthera tenella and Eleusine indica. Living with this community throughout the cycle resulted in reduction almost $85 \%$ in cotton yield.
\end{abstract}

Keywords: Gossypium hirsutum. Weed. Competition. Productivity.

\section{PERÍODOS DE INTERFERÊNCIA DAS PLANTAS DANINHAS EM ALGODOEIRO TRANSGÊNICO IMACD 6001LL}

\begin{abstract}
RESUMO - O objetivo deste trabalho foi determinar os períodos de interferência das plantas daninhas e suas consequências na produtividade da cultura do algodão 'IMACD 6001LL'. O experimento foi realizado na safrinha 2011 e constou de dois grupos de tratamentos: no primeiro a cultura permaneceu livre da competição das plantas daninhas desde a emergência até épocas crescentes de seu ciclo de desenvolvimento: $(0-15 ; 0-25 ; 0$ $35 ; 0-45 ; 0-55 ; 0-65 ; 0-75$ e $0-183$ dias - colheita). No segundo grupo de tratamento realizou-se o contrário: a cultura permaneceu em convivência com as plantas daninhas desde a emergência até os mesmos estágios de desenvolvimentos descritos anteriormente. Os tratamentos experimentais foram dispostos no delineamento em blocos casualisados, em quatro repetições. Nestes períodos foi avaliada a matéria seca acumulada pela comunidade infestante geral e específica. Os dados de produtividade do algodoeiro foram submetidos à análise de regressão resultando em um PAI de 35 dias após a emergência (DAE), o PTPI foi de 133 DAE. A comunidade infestante composta principalmente por Raphanus raphanistrum, Amaranthus spp., Cyperus rotundus, Eleusine indica e Alternanthera tenella, presente todo o ciclo da cultura acarretou em quase $85 \%$ de perda na produtividade do algodoeiro.
\end{abstract}

Palavras-chave: Gossypium hirsutum. Infestantes. Competição. Produtividade.

\footnotetext{
${ }^{*}$ Corresponding author

${ }^{1}$ Received for publication in $08 / 06 / 2015$; accepted in $01 / 21 / 2016$.

Paper extracted from the monograph to graduate in agronomy of the first author.

${ }^{2}$ Department of Applied Biology, Universidade Estadual Paulista, Jaboticabal, SP, Brazil; marcospaulo_agro07@hotmail.com, fnunes.agro@yahoo.com.br, plalves@fcav.unesp.br.

${ }^{3}$ College of Agronomy, Universidade Federal do Pará, Cametá, PA, Brazil; mcparreira@ufpa.br.
} 


\section{INTRODUCTION}

Brazil is among the five largest producers of cotton, alongside countries like China to India, the US and Pakistan. In the last three seasons, the Brazilian production of plumes reached 1.7 million tons, the largest producer of this matter in Latin America (ABRAPA, 2015). High productivity is by use of varieties adapted to climate and soil conditions in Brazil, tolerance to disease problems, cultivars with higher yield potential, in addition to the use of modern farming techniques (LATORRE, 2014).

Weeds consist of the main biotic component of influence in cotton, which has great susceptibility to interference caused by them, may be reported losses of more than $90 \%$ productivity (CARDOSO et al., 2010).

The critical period of weed control (CPWC) is the period during the crop cycle in which weeds must be controlled in order to avoid reduction in crop yield. The CPWC starts in the critical timing of weed removal (CTWR), corresponding to the maximum amount of time that early-season weed competition can be tolerated by the crop before it suffers yield reduction, and it ends in the critical weed-free period (CWFP), corresponding to the minimum weed-free period required to prevent yield reductions (KNEZEVIC et al., 2002).Theoretically, crop yield is only marginally influenced if the weed control occurs before or after the CPWC.

The genetically modified crops resistant to herbicides event arose from the need to facilitate weed management and enable the selectivity of herbicides for crops. Currently they are registered and approved by the Commission Biosafety Technical resistant cotton cultivars to herbicides glyphosate and glufosinate ammonium. However the behavior of cultivars resistant to herbicides in the weeds is still object of study. Thus the objective of this research is to check the behavior of a transgenic farming in competition with weeds determining periods of interference and result in productivity.

\section{MATERIAL AND METHODS}

This experiment was carried out in the field, in Jaboticabal, state of São Paulo, which is in latitude $21^{\circ} 15^{\prime} 22$ "S, longitude $48^{\circ} 18^{\prime} 58^{\prime \prime} \mathrm{E}$, altitude of 595 meters. The soil of the experimental area was classified as Oxisol clayey, the results of chemical are shown in table 1. Prior to the experiment, the area was planted with corn in the conventional system, not occurring herbicide application. The data precipitation and temperatures in the trial period are shown in Figure 1.

Table 1. Chemical composition of the soil in the experiment plot.

\begin{tabular}{cccccccccc}
\hline \hline $\begin{array}{c}\mathrm{pH} \\
\mathrm{CaCl}_{2}\end{array}$ & $\mathrm{~K}$ & $\mathrm{Ca}$ & $\mathrm{Mg}$ & $\begin{array}{c}\mathrm{H}+\mathrm{Al} \\
\mathrm{mmolc} \mathrm{dm}^{-3}\end{array}$ & $\mathrm{SB}$ & $\mathrm{T}$ & $\begin{array}{c}\text { P resina } \\
\mathrm{mg} \mathrm{dm}^{-3}\end{array}$ & $\begin{array}{c}\text { M.O. } \\
\mathrm{g} \mathrm{dm}^{-3}\end{array}$ & $\begin{array}{c}\mathrm{V} \\
\%\end{array}$ \\
\hline 5 & 1,8 & 18 & 6 & 31 & 25,8 & 56,8 & 111 & 11 & 45 \\
\hline
\end{tabular}

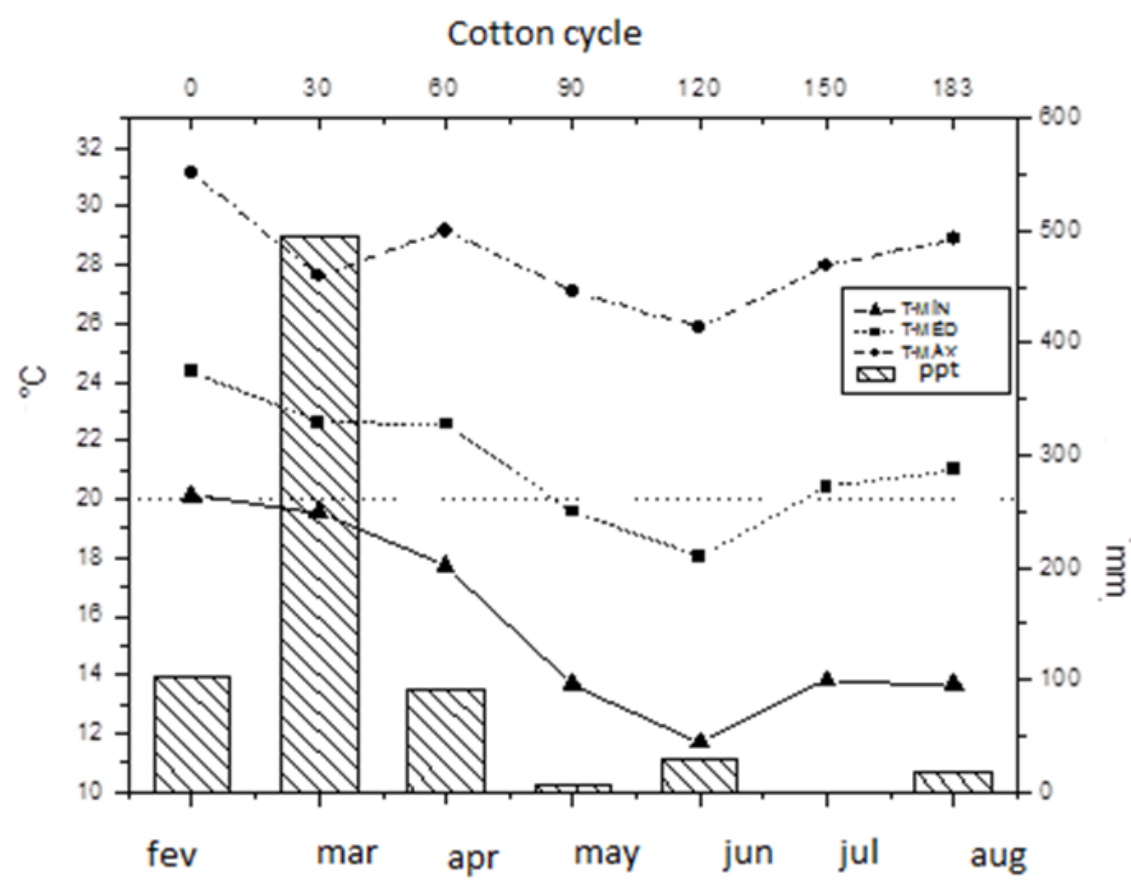

Figure 1. Precipitation, maximum, media and minimum temperatures during the trial period. 
Soil preparation was done in the conventional system, with a then plowing disking. Sowing was carried out on 16/02/2011 mechanized (seeder fertilizer Jumil EXACT air PD 2640) at a density of 11 seeds per meter, with spacing of $0.90 \mathrm{~m}$ between lines, was not performed herbicide application prior to sowing . The cultivar used was IMACD 6001LL, transgenic material (Liberty $\operatorname{Link}{ }^{\circledR}$ ) resistant to glufosinate ammonium, having intermediate cycle of up to 160 days, average height, good quality fiber, resistant to stain ring and blue spot (DA SILVA et al., 2015). In sowing fertilization were used $340 \mathrm{~kg}$ $\mathrm{ha}^{-1}$ formulated 4-20-20 (NPK).

The experiment consisted of two treatment groups. In the first group, for the determination of the period before interference (CWFP) were evaluated nine increasing periods of cultural contact with the weeds after emergence of cotton (DAE): 0, $15,25,35,45,55,6575$ and 183 (harvest) days. After each period of coexistence was held control (manual) of the weeds until harvest. In the second group were evaluated nine increasing periods of control of weeds after emergence of cotton: 0, 15, $25,35,45,55,65,75,183$ (harvest) days. After the end of each period of control, was allowed to weeds emerge freely in order to estimate the total period of interference prevention (CTWR).

Removal of weeds at the end of each initial coexistence period, and the weekly maintenance of these free portions of the weeds to the closing lines of the culture was performed with manual weeding (spade). The increasing periods of control were also obtained with frequent manual hoeing operations which were interrupted as they reached the end of each period.

It was used a randomized block design with four replications. The plots were four planting rows with five meters long each, resulting in an area of 18 $\mathrm{m}^{2}$. The two outer rows of each plot were discarded, they are the borders; effectively, the useful area consisted of two central rows of each plot, resulting in $7.2 \mathrm{~m}^{2}$ sample.

The evaluation of the weed community was made at the end of each period, referred to in the plot. Weeds present at two sites, $0.25 \mathrm{~m}^{2}$, taken at random in the experimental plots were removed, identified, counted and dried in an oven with forced air at $70^{\circ} \mathrm{C}$ for 96 hours to determine the dry mass, held with the balance of aid to an accuracy of $0.01 \mathrm{~g}$.

To end the crop cycle and achieve a uniform crop, the application of a defoliant was made Thidiazuron + diuron $\left(0.5 \mathrm{~L} \mathrm{ha}^{-1}\right)$ to 176 days after emergence of the crop and the harvest was performed seven days after applying the defoliant, when the culture had $70 \%$ of the floor area open bolls. The harvest was done manually collecting the bolls (fiber and seed) only plants present in the effective floor area.

Data on cotton yields and weed interference periods were submitted to a regression analysis, fitting one curve for weed-free periods and another for weedy periods, using the sigmoid Boltzmann model, as follow

$$
y=\frac{(\mathrm{P} 1-\mathrm{P} 2)}{1+e^{\left(\mathrm{X}-\mathrm{x}_{0}\right) / \mathrm{dx}}}+\mathrm{P} 2, \text { where }
$$

where $\mathrm{Y}=$ seed cotton yield; $\mathrm{P} 1=$ maximum yield (from weed-free plots); P2 =minimum yield (from weedy plots during all of the cycle); $x=$ period of time in the treatment kept the longest weedy or weed free; $\mathrm{x} 0=$ weedy period of time in which cotton yield had the average value between the highest and the lowest yield; $\mathrm{dx}=$ calculated value to fit the equation corresponding to the tangent of the curve in the point $\mathrm{x} 0$.

The equations were used to estimate the periods in which weed interference reduced yields in $5 \%$ compared to the weed-free treatment (KUVA et al., 2000; KNEZEVIC et al., 2002). Calculations were made with the software MicroCal Origin v. 6.1 (OriginalLab Corporation, USA).

\section{RESULTS AND DISCUSSION}

The weed community was composed of 19 species, and distributed in 12 families (Table 2). The eudicotyledons accounted for $68.42 \%$, highlighting the Asteraceae and Amaranthaceae families with, respectively, four and five species as the most numerous. Monocotyledons represented 31.58\%, highlighting the Poaceae family with four species, with one species, Commelinaceae and Cyperaceae families. Salgado et al. (2002), working with Delta Opal-growing in the same area found 25 species of weeds, $64 \%$ of eudicotyledons and $36 \%$ of monocots. Raimondi et al. (2014) found $80 \%$ of eudicotyledons and $20 \%$ monocots in cotton in Chapadao do Sul (MS), showing that the eudicotyledons are more present in this culture, regardless of the place of cultivation. 
Table 2. Weed community of the experimental area.

\begin{tabular}{|c|c|c|c|}
\hline Family & Scientific name & Popular name & \\
\hline Amaranthaceae & $\begin{array}{c}\text { Alternanthera ficoidea (L.) SM } \\
\text { Amaranthus deflexus L. }\end{array}$ & $\begin{array}{l}\text { Apaga-fogo } \\
\text { Caruru }\end{array}$ & Dicots \\
\hline Asteraceae & $\begin{array}{l}\text { Acanthospermum hispidum DC } \\
\text { Bidens pilosa } \mathrm{L} . \\
\text { Xanthium strumarium } \mathrm{L} . \\
\text { Ageratum conyzoides } \mathrm{L} .\end{array}$ & $\begin{array}{c}\text { Carrapicho-de-carneiro } \\
\text { Picão-preto } \\
\text { Carrapichao } \\
\text { Mentrasto }\end{array}$ & Dicots \\
\hline Brassicaceae & Raphanus raphanistrum $\mathrm{L}$. & Nabiça & Dicots \\
\hline Chenopodiaceae & Chenopodium ambrosioides $\mathrm{L}$. & Mastruz & Dicots \\
\hline Convolvulaceae & Ipomoea grandifolia (Dammer) O’Donell & Corda- de-viola & Dicots \\
\hline Commelinaceae & Commelina benghalensis L. & Trapoeraba & Monocots \\
\hline Cyperaceae & Cyperus rotundus $\mathrm{L}$. & Tiririca & Monocots \\
\hline Euphorbiaceae & Euphorbia heterophylla L. & Leiteiro & Dicots \\
\hline Malvaceae & Sida rhombifolia L. & Guanxuma & Dicots \\
\hline Poaceae & $\begin{array}{l}\text { Cenchrus echinatus } \mathrm{L} . \\
\text { Digitaria } \text { sp. } \\
\text { Eleusine indica }(\mathrm{L} .) \text { Gaertn } \\
\text { Panicum maximum Jacq. }\end{array}$ & $\begin{array}{l}\text { Capim-carrapicho } \\
\text { Capim-colchão } \\
\text { Capim-pé-de-galinha } \\
\text { Capim-colonião }\end{array}$ & Monocots \\
\hline Portulacaceae & Portulaca oleracea $\mathrm{L}$. & Beldroega & Dicots \\
\hline Solanaceae & Nicandra physalodes (L.) Pers. & Nicandra & Dicots \\
\hline
\end{tabular}

In terms of dry matter accumulation of weeds in the control period, there was an increase up to 15 days after emergence (DAE), when it reached the maximum of $5042.56 \mathrm{~g} \mathrm{~m}-2$ (Figure 2). From that time, was the reduction in dry matter accumulation, due to the amount of rainfall and the crop shading on the weeds providing further development of the same, because with increasing periods of control there is also increased competition for part of the culture, thus influencing the physiology of plants present in the area, resulting in this case, reduction of total dry matter.

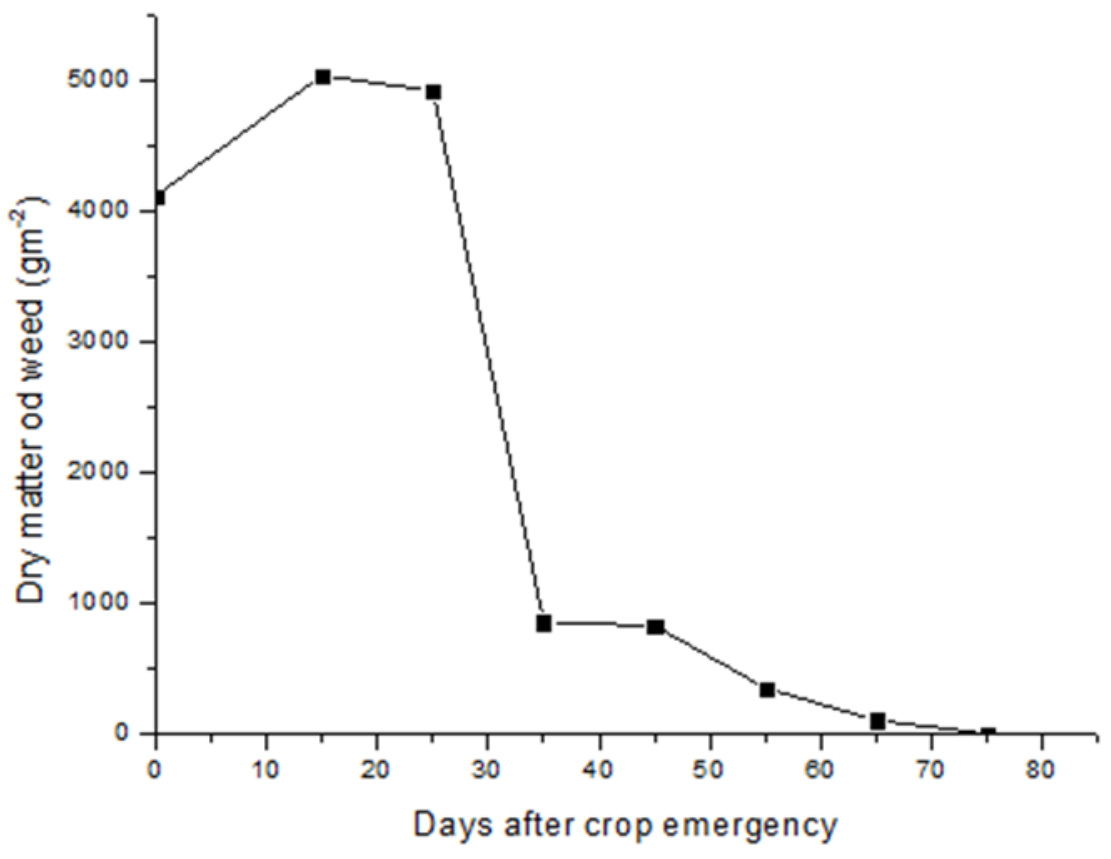

Figure 2. Total dry matter of weeds as a function of the control periods.

In Figure 3 shows that with increasing periods of coexistence of weeds with culture, also increased the accumulation of dry matter of weeds, and at the beginning of the cycle (15 DAE) dry weight increased until the $25 \mathrm{DAE}$, reaching $194.08 \mathrm{~g} \mathrm{~m}^{-2}$, markedly progressing to 75 DAE, when the dry matter accumulation reached $3793.8 \mathrm{~g} \mathrm{~m}^{-2}$. The growing accumulation of dry matter was intensely since the beginning of the treatment plants had availability of all resources, especially water. 


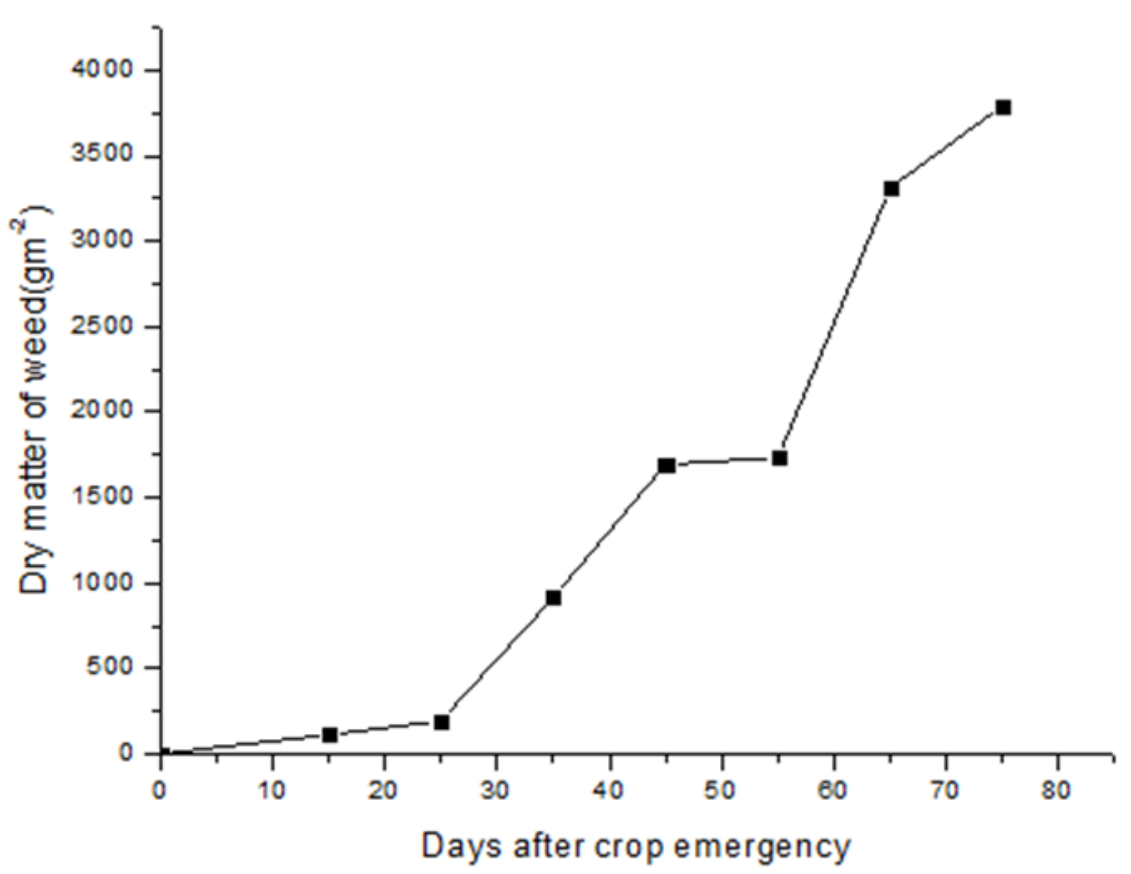

Figure 3. Total dry matter of weeds as a function of the periods living together.

The weeds that had higher sum of dry matter in the control period of weed community were Raphanus raphanistrum (RAPRA), Amaranthus spp. (AMASP), Eleusine indica (ELEIN) and Alternathera tenella (ALRTE) observing maximum accumulation at $15 \mathrm{DAE}$ with $2,600 \mathrm{~g} \mathrm{~m}^{2}$ of $A$. tenella, there is a general decrease after 25 DAE (Figure 4). According to Raimondi et al (2014), the dry matter parameter of weeds in competition with the cotton crop is one of the most important, is the feature that most correlates with productivity.

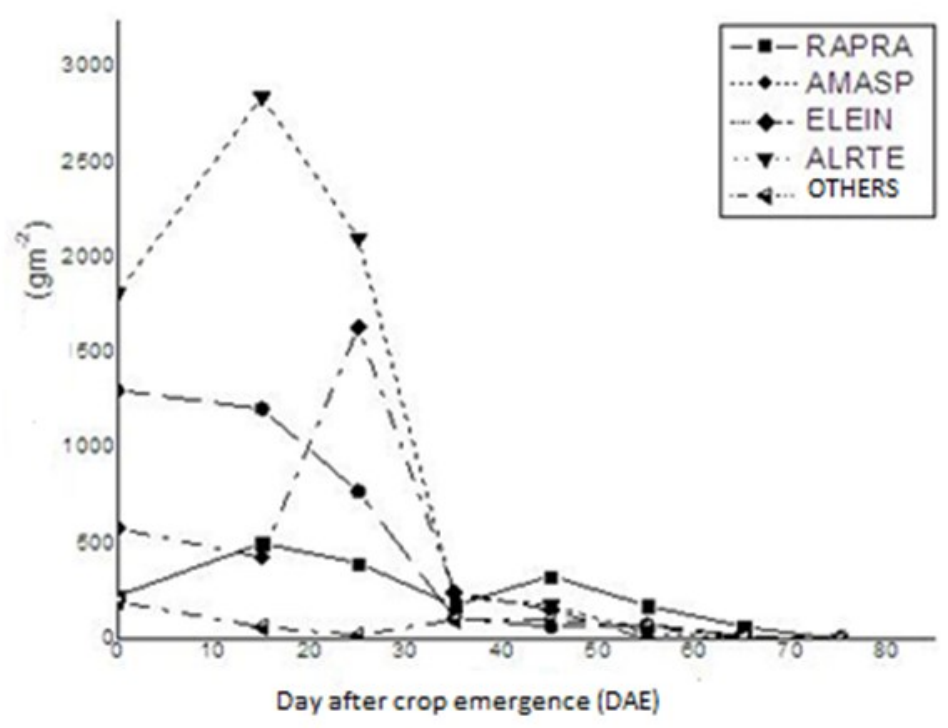

Figure 4. Weed dry matter a function of coexistence of periods.

In treatments for the coexistence period highlighted the accumulation of dry matter: $R$. raphanistrum, Amaranthus spp, C. rotundus, E. indica and A. tenela (Figure 5). The weeds found in this experiment in high density are among the three most im- portant weeds of the world (HOLM, 1991). The E. indica indicates, which was observed in great abundance in this research, it was also found with one of the largest accumulations of dry matter in the coexistence period, the cultivar BRS 293 cotton sown in 
the off-season period (RAIMONDI et al, 2014).

The turnip was the predominant species, with $1.700 \mathrm{~g} \mathrm{~m}^{-2}$ of dry matter, followed by extinguishes fire with $900 \mathrm{~g} \mathrm{~m}^{-2}$, Amaranthus spp with about 600 $\mathrm{g} \mathrm{m}^{-2}$, E. indica with $200 \mathrm{~g} \mathrm{~m}^{-2}$ and C. rotundus with approximately $50 \mathrm{~g} \mathrm{~m}^{-2}$ at 75 DAE. Scholten et al. (2011), Parreira et al. $(2013,2014)$ and found that, in $R$. raphanistrum reached extremely high density and dry weight values drastically reducing crop yields that were present.

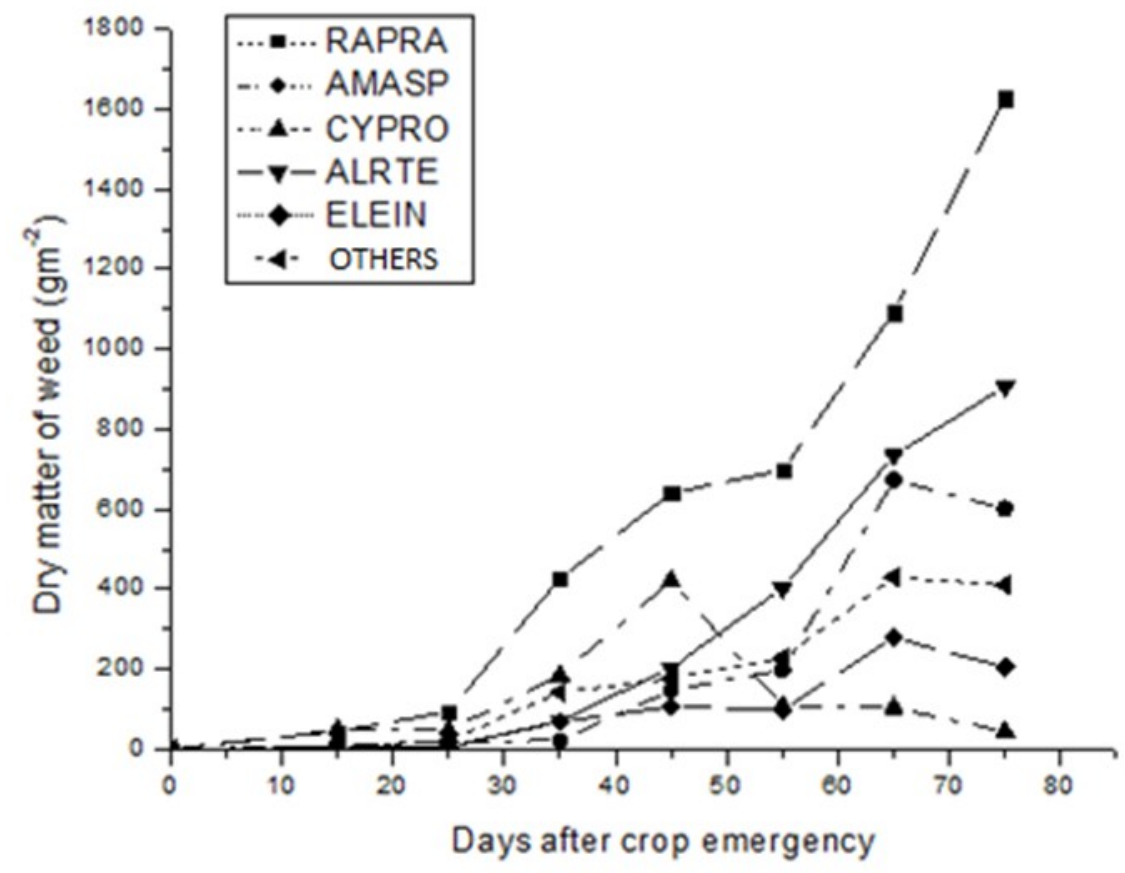

Figure 5. Weed dry matter as a function of control periods.

When analyzing productivity when the weed community was present throughout the crop cycle, there were drastic losses in production reducing $84.89 \%$. The production obtained in the total absence of weeds (witness the clean) was $1810.83 \mathrm{~kg} \mathrm{ha}^{-1}$, reduced to $273.54 \mathrm{~kg} \mathrm{ha}^{-1}$ when present throughout the cycle (control in the forest) (Table 3 and Figure 6). In a similar study, but accomplished with cultivar Delta-Opal, Salgado et al. (2002) observed that the weeds that grow committed to $97 \%$ productivity. Cardoso et al. (2011) researching the naturally colored cotton production, BRS Verde, verified reduction of more than $82 \%$ to be weeds in harmony with the culture.

According Ballare; Casal (2000) in a culture where there weeds, they can change, plus the quantity, quality of incident light on the ground and thus affect the development of the crop. Facts these show that the weed community if not handled properly, the damage caused will be drastic above $80 \%$ in productivity, whether cotton genotype is conventional or transgenic.

Table 3. Boltzmann equations for yield (Y) in function of days after emergence (X) of cotton cv. IMACD 6001LL.

\begin{tabular}{cccc}
\hline \hline Parameters & Weedy & Weed Free & \\
\hline A1 & 169,36 & 19,37 & Boltzman Equations \\
A2 & 26,76 & 161,33 & \\
$\mathbf{X}_{\mathbf{0}}$ & 44,99 & 52,81 & $\mathrm{Y}=\frac{(\mathrm{A} 1-\mathrm{A} 2)}{1+e^{\frac{(X-X o)}{d x}}+\mathrm{A} 2}$ \\
$\mathbf{d X}$ & 3,61 & 15,58 & \\
$\mathbf{R}^{\mathbf{2}}$ & 0,95 & 0,9418 & \\
\hline \hline
\end{tabular}

\footnotetext{
*Significant at $5 \%$ in $\mathrm{F}$ test
} 


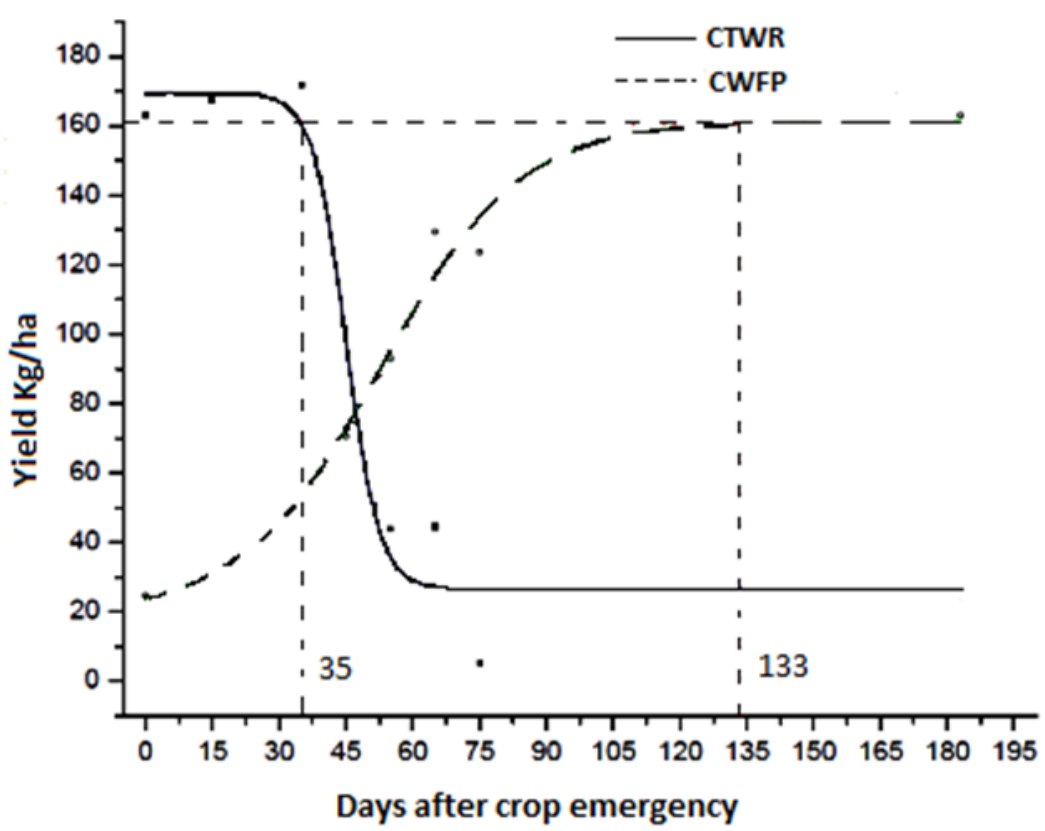

Figure 6. Critical periods of weed control (CPWC) in cotton cv. IMACD 6001LL estimated for yield loss of 5\% in Jaboticabal, 2011. CTWR: critical time of weed removal; CWFP: critical weed-free period.

Tolerating maximum $5 \%$ reduction in cotton productivity levels in this level they were achieved from 35 days of emergence (DAE), corresponding this way CWFP. Vidal et al. (2008) showed that the weeds that compete for light at the beginning of the cotton cycle are very harmful, especially by competition for water and nutrients, which is one of the main reasons to observe reductions in crop productivity.

On the other hand, the weed control (CPWR) was found to be extensive, at 133 DAE (Figure 5). One of the causes of this high CPWR is due to the plant architecture and slow closing of culture, providing ideal conditions for development for the weed community (LAMEGO et al., 2005).

The critical period for preventing interference (CTWR) found was 98 days. In practice, it is the period that the weed control should be performed, either with hoeing (physical control) or with residual herbicides (chemical control), because all the weeds that emerge and stabilize the culture during this period promote interference and significantly reduce the crop yield (PITELLI, 1985).

The research carried out to determine the cotton coexistence periods with weeds show that there is a strong influence of the factors that determine the degree of interference, making the results vary from account to account, and that CWFP may be near 10 DAE (FORSTER; PAUL, 1994; AZEVEDO et al., 1993; BELTRÃO; MELHORANÇA, 1998, RAIMONDI et al. 2014), while the CTWR was close to 55 DAE.

However authors such as Salgado et al. (2002); Papamichail et al. (2002); Christoffoleti et al.
(2007), and Cardoso et al. (2011) observed CWFP was approximately $8 \mathrm{DAE}$ and CTWR could reach up to 96 DAE. Results may vary from year to year according, even using similar cultivars and same planting sites (ERMAN, 2008; SWANTON et al, 2010;. KAVURMACI et al, 2010). These facts show that all the factors that influence the degree of weed interference in culture should be considered, especially those related to plant, soil, climate and crop management (PITELLI, 1985). However, in all reported data, the mere presence of weeds in the area, with the cotton crop, regardless of the crop genotype, caused significant and irreparable losses in productivity.

\section{CONCLUSION}

Assuming maximum 5\% loss of productivity were certain periods of 35 and 133 to CWFP and the CTWR, respectively, with duration of CPWC 98 days. The weed community mainly composed of $R$. raphanistrum, Amaranthus spp., $C$. rotundus, $E$. indica and $A$. tenella resulted in reduction of almost $85 \%$ in productivity in transgenic cotton crop IMACD $6001 \mathrm{LL}$.

\section{REFERENCES}

ABRAPA - Associação Brasileira dos Produtores de Algodão. 2015. Disponível em: <http:// abrapa.com.br/>. Acessado em: 22 jun. 2015. 
AZEVEDO, D. M. P. et al. Manejo de plantas daninhas no cultivo do algodoeiro herbáceo. Campina Grande: EMBRAPA-CNPA, 1993, 11 p. (comunicado técnico, 35).

BALLARÉ, C. L.; CASAL, J. J. Light signals perceived by crop and weed plants. Field Crops Research, Amsterdam, v. 67, n. 2, p. 149-160, 2000.

BELTRÃO, N.E. de M.; MELHORANÇA, A.L. Plantas daninhas: importância e controle. In: ALGODÃO: informações técnicas. Dourados: Embrapa-CPAO; Embrapa-CNPA, 1998. 267p. (Embrapa-CPAO. Circular Técnica, 7).

CARDOSO, G. D. et al. Períodos de interferência das plantas daninhas em algodoeiro de fibras coloridas ' BRS Safira'. Ver. Ciência Agronômica, Fortaleza, v. 41, n. 3, p. 46-52, 2010.

CARDOSO, G. D. et al. Critical periods of weed control in naturally green colored cotton BRS Verde. Industrial Crops and Products; Amsterdam, v. 34, n.1, p. 1198-1202, 2011.

CHRISTOFFOLETI, P. J. et al. Manejo de plantas daninhas na cultura do algodão. In: FREIRE, E. C. (Ed.). Algodão no Cerrado do Brasil. Brasília: Associação dos Produtores de Algodão, 2007. v.1, cap. 14, p. 523-550.

DA SILVA, A; K; F. et al. Complete genome sequences of two new virus isolates associated with cotton blue disease resistance breaking in Brazil. Archives of Virology, London, v. 160, n. 5, p. 13711374, 2015.

ERMAN, M. Critical period of weed control in winter lentil under non-irrigated conditions in turkey. African Journal Agricultural Research, Windhoek, v. 3, n. 6, p. 523-530, 2008.

FORSTER, R.; PAULO, E. M. Período de competição de populações de gramíneas e dicotiledôneas, vegetando em separado, na cultura do algodão. In: CONGRESSO BRASILEIRO DE HERBICIDAS E PLANTAS DANINHAS, 15., 1984, Belo Horizonte. Anais... Belo Horizonte: SBCPD, 1984. p. 38

HOLM, L. G. et al. The world's worst weeds. Malabar: Krieger Publishing Company, 1991. 609 p.

KAVURMACI, Z. et al. Determining critical period of weed crop competition in faba bean (Vicia faba). International Journal of Agriculture and Biology, Faisalabad, v. 12, n.2, p. 318-320, 2010.

KNEZEVIC, S. Z. et. al. Critical period for weed control: the concept and data analysis. Weed
Science, Lawrence, v. 50, n. 6, p. 773-786, 2002.

KUVA, M. A. et al. Períodos de Interferência das plantas daninhas na cultura da cana-de-açucar. I Tiririca. Planta Daninha, Viçosa, v. 18, n. 2, p. 245 $251,2000$.

LAMEGO, F. P. et al. Tolerância a interferência de plantas competidoras e habilidade de supressão por cultivares de soja - I. Resposta de variáveis de crescimento. Planta Daninha, Viçosa, v. 23, n. 3, p. 405-414, 2005

LATORRE, D. O. Intoxicação e alterações metabólicas do algodão sensível e resistente ao amônio glufosinate. 2014, 65 f. Dissertação (Mestrado em Agricultura) - UNIVERSIDADE ESTADUAL PAULISTA “JÚLIO DE MESQUITA FILHO, UNESP, Botucatu, 2014.

PAPAMICHAIL, D. et al. Critical periods of weed competition in cotton in Greece. Phytoparasitica, Switzerland, v. 30, n. 1, p. 105-111, 2002.

PARREIRA, M. C. et al. Interferencia de malezas en el cultivo de frijol en dos sistemas de labranzas. Planta Daninha, Viçosa, v. 31, n. 2, p. 319-327, 2013.

PARREIRA, M. C. comparação entre métodos para determinar o período anterior à interferência de plantas daninhas em feijoeiros com distintos tipos de hábitos de crescimento. Planta Daninha, Viçosa, v. 32 , n. 4 , p. $727-738,2014$

PITELLI, R. A. Interferência de plantas daninhas em culturas agrícolas. Informe Agropecuário, Belo Horizonte, v. 11, n. 129, p. 19-27, 1985.

RAIMONDI, M. A. et al. Períodos de interferência das plantas daninhas na cultura do algodão em semeadura adensada na safrinha. Planta Daninha, Viçosa, v. 32, n. 3, p. 521-532, 2014

SALGADO, T. P. et al. Períodos de interferência das plantas daninhas na cultura do algodoeiro (Gossypium hirsutum). Planta Daninha, Viçosa, v. 20, n. 3, p. 373-379, 2002.

SCHOLTEN, R.; PARREIRA, M. C.; ALVES, P. L. C. A. Período anterior à interferência das plantas daninhas para cultivar de feijoeiro 'Rubi' em função do espaçamento e da densidade de semeadura. Acta Scientiarum. Agronomy, Maringá, v. 33, n. 2, p. 313-320, 2011

SWANTON, C. J.; O'SULLIVAN, J.; ROBINSON, D. E. The critical weed-free period in carrot. Weed Science. Lawrence, v. 58, n. 3, p. 229-233, 2010. 
VIDAL, R. A. et. al. Initialism: a new term to describe the first mechanism of negative interaction between weeds and crops. Journal of Plant Diseases and Protection, Braunschweig, v. 21, n. 1, p. 95-98, 2008. 